Review

\title{
Organizational Sustainability Practices: A Study of the Firms Listed by the Corporate Sustainability Index
}

\author{
Alamo Alexandre da Silva Batista * and Antonio Carlos de Francisco \\ Department of Production Engineering, UTFPR-Federal University of Technology-Paraná, \\ Av. Monteiro Lobato, km 04, 84016-210 Ponta Grossa, Paraná, Brazil; acfrancisco@utfpr.edu.br \\ * Correspondence: alamobatista@utfpr.edu.br; Tel.: +55-042-3220-4872
}

Received: 27 December 2017; Accepted: 15 January 2018; Published: 17 January 2018

\begin{abstract}
Organizational sustainability (OS) has been guiding the decision-making process of managers in order to generate competitive advantage. This paper aims to identify the sustainable practices performed by large corporations in the implementation of OS. Reports with actions performed by large organizations and their reach in the three pillars of sustainability-environmental, economic, and social dimensions-are disclosed to their main stakeholders, based on short, medium and long-term sustainable goals. These reports often reflect the progress of OS or the progress made toward them. However, few studies investigate the sustainable practices adopted by firms and their reproducibility. A search was performed in reports selected from the firms listed by the Corporate Sustainability Index (CSI) from 2012-2016, belonging to the Brazilian stock market in services sector of the economy and employed the Global Reporting Initiative (GRI) methodology. The results showed the strategic planning involving infrastructure, environment, human resources, product innovation, organizational management and deadline setting acted as the baseline for the implementation of the practices found. The findings will guide the managers' decisions in the development of their strategic planning, based on practical and objective results.
\end{abstract}

Keywords: organizational sustainability; sustainability report; sustainability practices; corporate sustainability index

\section{Introduction}

This paper aims to identify the practices performed by firms recognized by third parties as sustainable in environmental, economic, and/or social dimensions. OS implementation is complex and needs the participation of the interested parts [1]. Siew [2] conducted a review regarding the main methodologies employed to assess sustainability. Amui et al. [3] focused on the dynamic and needs of sustainability and [4] on the quality of the corporate sustainability reports. This paper complements those works with a holistic view of the system through the analysis and assessment of the main sustainability categories, observing the recognized practices performed by large, corporations that are acknowledged as being sustainable.

This research will inform managers on the sustainable practices currently employed in order to support their decision-making in strategic planning. The discernment and the ability to learn from the successful experiences of other firms is essential to get a competitive advantage [5]. Several studies view sustainability, its consequences and the potential gains for organizations only conceptually [6-8], lacking practical applications in the business day-to-day and appearing to be only superficial from the manager's perspective [9]. This paper seeks to complement those concepts and bridge this gap. OS has become prominent in the day-to-day of firms due to the several stages included in its implementation and operationalization [10].

Adopting this methodology of work with sustainable strategies and practices has been a constant challenge for managers, who need to conciliate competitiveness and profitability in the bottom line 
of their actions [11,12]. Large firms have been focusing their investments in the development of OS $[8,13,14]$. Thus, one of the ways in which firms attempt to maintain competitiveness is the search for sustainable practices in other markets or innovating already-existent ones [15]. This can help to improve the use of the resources and create the conditions to get a competitive advantage [14].

The main principle of OS is in the [16], which states that the current needs of organizations must not compromise the needs of future generations. Since then, several initiatives have been created to encourage sustainable consumption and industrial practices [17]. The inclusion of [18] triple bottom line concept, a business approach of OS was developed encompassing the environmental, economic, and social dimensions $[19,20]$, which has been guiding the decisions of managers, who in turn attempt to operationalize those concepts in their day-to-day through standards, codes or metrics [21].

Thus, sustainable practices vary depending on the firm's size, level of business maturity, strategic planning, and organizational structure, and this variation presents a challenge when implementing, analyzing, and identifying possible improvements for sustainable practices [2]. Therefore, firms plan and operationalize their activities in the short, medium, and long-term based on OS [8], based on innovation and tools to improve and implant the sustainability on their business [22]. Environmental and social matters are also being taken into account in the stakeholders' analysis-researchers, investors, customers, governments, and civil society—in addition to economic performance [23]. Among the several ways to document those practices, sustainability reports have grown in popularity, following the guidelines established by the Global Reporting Initiative (GRI), which are the most employed and accepted internationally [21,24].

These reports have become important tools to assess and illustrate the OS practiced by organizations [25]. They afford the opportunity to measure the sustainable development of organizations within a specific set of standards and indices [11], seeing that many corporations are warned about their responsibility in environmental and social impacts [8]. Several organizations have been measuring and managing their OS practices through these reports, which have allowed a gradual growth of OS ideology within them [26].

Companies that voluntarily fill out and disclose their sustainability reports is also growing [24] and based on the activities and the impacts caused, the main stakeholders penalize or reward the firms [23]. Sustainability reports provide firms with the opportunity to improve their transparency, market value, reputation, and legitimacy. They also enable benchmarking against their competitors and motivate their collaborators [25]. In addition, they are an important tool that contributes to the development and evolution of OS, demonstrating the interdependent relations between the social, economic, and environmental dimensions [27]. However, there is the issue of reconciling those different dimensions within a single organization, due to conflicting interests in different departments and managers $[7,26]$.

Moreover, there are several criticisms from managers who defend that the reports are only superficial indices, lacking a practical aspect and often limited to large corporations, with no applicability in their day-to-day [28]. In order to eliminate said superficiality and create practical activities, there needs to be a change in behavior, culture, and alignment of interests and goals [3]. There are several international indices that rank and map firms in terms of their sustainable activities, such as the Global Reporting Initiative, the Dow Jones sustainability index, Greenwashing index, Global 100 and Newsweek Green Rankings, Greenhouse Gas Protocol Initiative (GHG Protocol), in addition to regulation norms such as Social Accountability 8000, ISO 14,000 and 26,000 [9,23,29].

In Brazil, there is the CSI (ISE-Índice de Sustentabilidade Empresarial in Portuguese translation) maintained by IBOVESPA, which lists the firms that meet the minimum OS requirements [30]. For the purpose of solving the superficiality issue, this paper intends to answer the following question: What are the actions performed by large corporations in the implementation of organizational sustainability? In order to reach this objective, a systematic data collection in the GRI database searching for firms, listed by the CSI from 2012 to 2016, that filled out the GRI-G4 report. Brazil was chosen for this research because of the economic recession and the economical volatility, and as a 
consequence, a growing unemployment [31,32]. The consequence for this situation is the increasing of entrepreneurs acting on service sector [33]. Only the service sector and its sub-sectors was analyzed, seeing that they represented 73.3\% of Brazil's GDP in 2016 [34].

This paper has the following structure: Section 2 presents a brief review on sustainability reports, the CSI and the service sector in Brazil, Section 3 explains the research method employed in the literature review and the data collection from the database, Section 4 displays the results and discussion, and Section 5 presents the conclusions.

\section{Literature Review}

\subsection{Sustainability Reports}

In order to be able to implement OS guidelines, a firm needs its managers to innovate their perception regarding the efficiency of its products, services, and technologies employed in its processes [27]. Because of that need, organizations have become increasingly more interested in applying sustainability to its day-to-day and disclosing its actions to their stakeholders through sustainability reports [6,24]. Either through market needs or due to specific legislation, sustainability reports have become an important tool to communicate the sustainable activities implemented by organizations [35].

Companies are able to benefit from this information, to come out of theory and provide a practical aspect, capable of affording a competitive advantage [36]. The capability of transforming the OS concept into action with practical initiatives can alter this scenario [37]. Over the past few years, firms have increased their participation in releasing their reports following GRI guidelines, which encompasses the three variables in the triple bottom line and is one of the most employed and recognized worldwide [38]. Preparing and release of these reports are voluntary [39], except in a few countries in the European Union that have specific legislation that dictates the release of the reports [40].

Several developed countries utilize a standard system to analyze the information regarding sustainability, so as to ensure that the decision-makers have a solid grounding in their strategic planning [41]. In Brazil, there is no specific legislation that forces firms to release their reports. In this regard, the number of firms in Brazil that voluntarily prepare and release their reports according to GRI guidelines has been growing.

Firms that intend to standardize their reports are willing to show their stakeholders their planning to follow international guidelines in the implementation and assessment of sustainable practices [27,42]. Despite the set of guidelines, there is still a certain difficulty to observe and collect the information contained in the reports, due the individuality of the organizations and the lack of understanding on how the firms measure the results of those practices, which is not informed by the reports [26].

\subsection{Corporate Sustainability Index}

The stock market presents several indices in order to provide their investors with new investment options. Those indices display the performance of capital markets and the price behavior of the stocks listed by them [31]. Investors search for firms that present OS policies, transparency principles, and good corporate governance [43]. The CSI indices meet this specific demand, including social, environmental dimensions and corporate governance, highlighting the firms that are excellent in the OS aspect $[29,44]$.

One of the most well-known instances is the Dow Jones Sustainability Index, which represents $10 \%$ of a total of 2500 firms listed by the Dow Jones index [45]. In Brazil, CSI is maintained and managed by IBOVESPA, which was created in 2005. CSI's scope is to analyze corporate sustainability focusing on the following aspects: environmental, social, economic and corporate governance. CSI is composed of 38 actions of 34 companies belonging to IBOVESPA, representing 15 different sectors [30]. 
The number of firms seeking to participate in the CSI has been growing significantly and, therefore, sustainability-related matters can be improved due to investors demanding better performances [29].

CSI is analyzed and renewed yearly, and the participation is voluntary [30]. In order to participate in the CSI, firms are required to meet the following minimum requisites: taking part in the 200 most-negotiated stocks in the current year, having at least 50\% daily negotiations, not having declared bankruptcy in any of its branches, not be responding to internal lawsuits against the CSI management, and not be suspended from the stock market [46]. These criteria display the importance and seriousness of the theme, becoming one more reason for firms to invest in and create goals toward implementing OS [31]. Orsato et al. [43] states that even though participating in a sustainability index is voluntary, firms obtain advantages in doing so, such as resource availability, OS institutionalization, competitive advantage, access to knowledge, and good reputation.

\subsection{Service Sector}

One of the existent methodologies to measure Brazil's GDP is the division of the main economic activities of the country into three sectors: the primary sector (agriculture), the secondary sector (industry), and the tertiary sector (services) [33]. In 2016, the service sector represented $73.3 \%$ of Brazil's GDP, while the industrial sector and the agricultural sector represented $21.2 \%$ and $5.5 \%$, respectively [34].

The tertiary sector is essential for the development of the Brazilian economy, seeing that it employs over $75 \%$ of the population and contributes to a growth in the sector despite the economic turbulence affecting the country [47]. Due to its representativeness and amplitude in the Brazilian economy, the service sector is analyzed by several institutions, which map the activities performed in order to contribute to its constant growth, provide management innovation, and utilize indices for better performances. Thus, even during a period of economic turbulence, it is a sector that employs and aggregates value to everyone directly or indirectly involved [48].

\section{Materials and Methods}

This paper followed the methodology proposed by [49] and the stages were followed:

(1) Developing a review of GRI sustainability reports

(2) Structuring a classification system for the areas approached by OS

(3) Mapping the results found in the classification system

(4) Identifying the results of the report analysis according to the classification

(5) Analyzing the results and suggesting future works.

Table 1 presents the activities conducted in each of the proposed stages. In stage 1, the main promoters of OS reports, encompassing the social, environmental and economic dimensions. GRI reports were selected due their status of most utilized worldwide. In the review planning, the criteria for searching and selecting the reports in the GRI database were: (1) service sector firms listed by the CSI in the 2012-2016 period; (2) identifying which of those firms published their reports according to GRI guidelines; (3) reports published in English. Stage 2 is the structuring of a classification system that organizes the results to facilitate understanding them. From the firms listed by the CSI in the analyzed time period, 190 firms were selected, which were then classified according to their field and categorized according to the criteria displayed in Table 1.

In stages 3 and 4 , the categories were identified and their respective practices displayed in the reports. Results were stored in an electronic spreadsheet in order to chart and present them. Finally, stage 5 consisted of writing the article and presenting the results, with the proper suggestions for future works. During the 2012-2016 period, 190 firms participated in the CSI and, after selecting the firms that act in the service sector, 71 reports were analyzed. 
Table 1. Methodology stages.

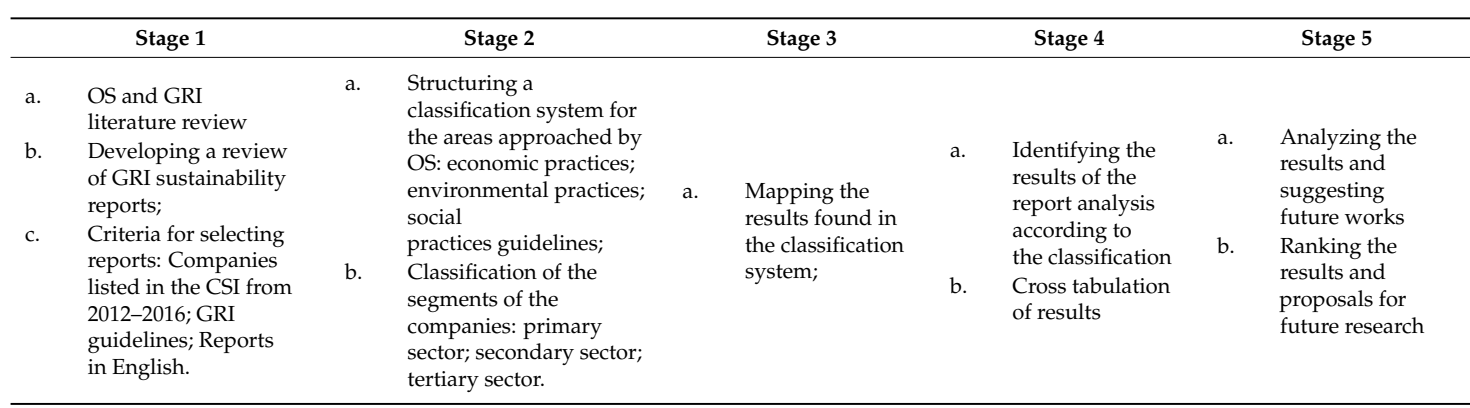

This time period was selected because sustainability involves a set of actions in medium to long-term, requiring constant analyses, updates, and adaptations when necessary $[10,26,35]$. Therefore, it was possible to find the current sustainable practices in the market and their maintenance by the firms. Figure 1 shows the number of reports analyzed throughout the research and their respective fields.

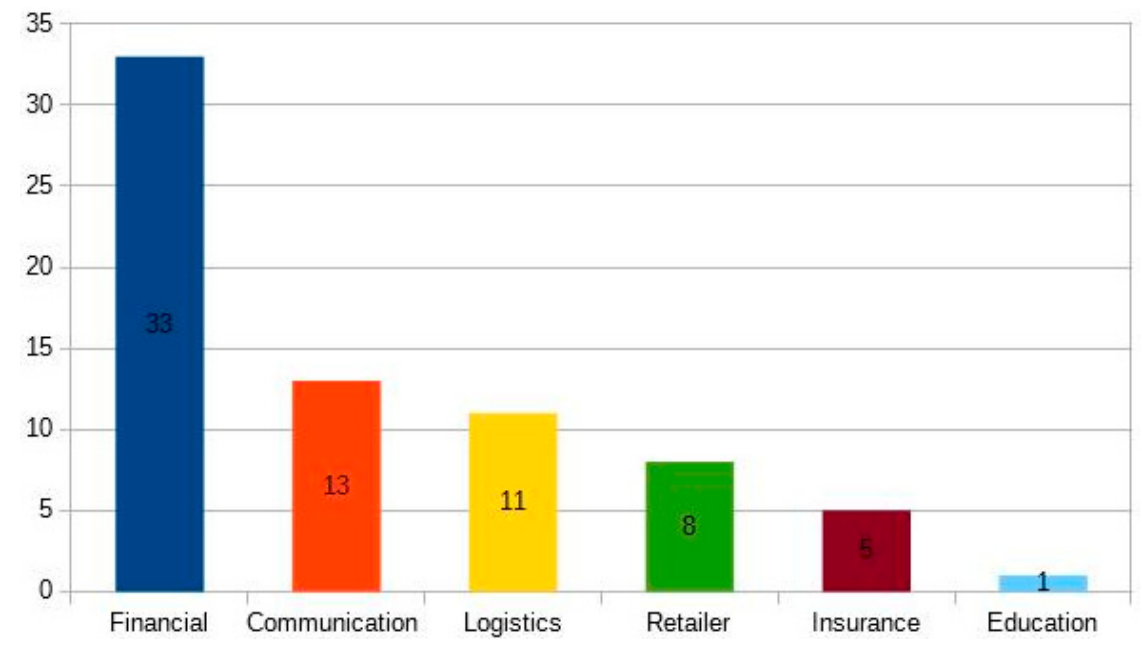

Figure 1. Analyzed reports.

Some firms participated in the CSI over the entire period; their reports were analyzed so as to ascertain whether there were eventual changes in their strategy. All of the firms followed the GRI standards, choosing to fill out the simplified or complete report model.

\section{Results and Discussion}

\subsection{Sustainability Practices-Environmental Category}

Table 2 displays the practices adopted by organizations in the implementation of sustainability in the environmental category. The practices found were fight against corruption, supplier management, focus on sustainability, risk management, capital and opportunities, employee satisfaction, and customer satisfaction. These results corroborate the findings of [50], which clearly demonstrate that organizations are constantly monitored by their investors and civil society, meeting the demands of stakeholders and other interested parts. Bellantuono et al. [51] argue that the stakeholders' participation is crucial for the development of a strategy with clear-cut objectives in the environmental aspect.

There is a special attention by their part toward the environmental practices adopted by organizations so that they act beyond the financial aspect $[31,52,53]$. Environmental performance is key in maintaining competitiveness, as a consequence of competitive behaviors and practices, meeting international demands and seeking a level of excellence required in developed countries [54]. Ignoring 
environmental strategies and other premises of sustainability means restricting the acting power and growth possibilities of firms drastically, losing real opportunities for long-term investments [55]. In the input (water and energy) and residues category, the actions were awareness campaigns for the internal and external public, gradual investment in infrastructure (for instance, energy management software, efficient air conditioners, rainwater harvesting), and periodic maintenance in the facilities.

Those actions corroborate the findings of $[54,56]$, which showed that the use of renewable resources is growing and the environmental performance is measured by actions toward reducing the consumption of natural resources, and contradict the findings of [57], who highlight that in many organizations the investment in environmental practices may be given low priority, to the detriment of the long-term economic returns that they may offer and the consequent attraction of capital.

Table 2. Environmental practices.

\begin{tabular}{|c|c|}
\hline Category & Practices \\
\hline Materials & $\begin{array}{ll}\text { 1. } & \text { Anti-corruption program } \\
\text { 2. } & \text { Supplier management } \\
\text { 3. } & \text { Sustainability } \\
\text { 4. } & \text { Risk management strategy } \\
\text { 5. } & \text { Client and worker satisfaction }\end{array}$ \\
\hline Energy/water & $\begin{array}{l}\text { 1. Investments in new technologies and } \\
\text { infrastructure update } \\
\text { 2. Awareness measures } \\
\text { 3. Infrastructure maintenance }\end{array}$ \\
\hline Effluents and waste & $\begin{array}{l}\text { 1. Selective collection and the proper disposal } \\
\text { 2. Awareness measures } \\
\text { 3. Reverse logistics }\end{array}$ \\
\hline Biodiversity & 1. Monitoring and control system, if applicable \\
\hline Transportation & $\begin{array}{l}\text { 1. Carbon emissions of the vehicles awarded and } \\
\text { its promotions } \\
\text { 2. Awareness measures for virtual meetings }\end{array}$ \\
\hline Emissions & $\begin{array}{l}\text { 1. Working toward GHG Protocol and } \\
\text { international certifications }\end{array}$ \\
\hline Environmental grievance mechanisms & $\begin{array}{ll}\text { 1. } & \text { Inspection visits and action plans } \\
\text { 2. } & \text { Audits } \\
\text { 3. } & \text { Comply with corporate social responsibility } \\
\text { 4. } & \text { Procurement professional code of ethical conduct }\end{array}$ \\
\hline
\end{tabular}

In the other categories, the use of specific contracts, cost reduction, and certifications guided the activities. The biodiversity category was present in only one segment (telecommunications), which reported the conduction of constant monitoring according to the specific environmental legislation.

The findings amplify the perspective of [52], who present environmental practices only in terms of utilizing and preserving natural resources (for instance, water use, gas emissions, etc.) and agree with [58] that the companies are responsible for the market and environmental solutions. The practices developed by firms encompass the entire chain involved in the process.

\subsection{Sustainability Practices-Economic Category}

In the category of economic performance, the practices that stood out were the development of strategic planning, investments in digital security, IT and human resources. The indirect economic impacts, according to the reports, were the development of new markets, possibilities for the generation of new jobs, greater actions toward accessibility, and adaptation to the new economic context. 
The purchase practices were the gradual implementation of an ethics code with the suppliers and the incentive to environmental practices.

Table 3 shows these practices and according to [57], the economic performance of firms that adopt OS is well-defined and structured, to the detriment of the other areas. According to [52], firms that possess a defined sustainable strategy are able to improve their financial situation and meet the demands of their stakeholders, without prioritizing any category. Sustainability categories must have the same priorities, in harmony with the internal and external public and not exclusively directed to economic matters [59].

The integration between the business plan and the sustainable strategies are crucial for the practices to achieve their objectives in the medium and long-term [60], amplifying the perspective proposed by [54]. Santis et al. [31] demonstrates that there is not a direct relationship between financial performance and sustainable actions, justifying the lack of incentives for those practices. The authors hold that sustainable practices have effects in the long-term, which reduces the attention of some managers. However, only in the medium and long-term will organizations be able to achieve the results expected from sustainability, which demands a judicious planning reaching both society and organization [13].

The time factor and the acting dynamic are essential for this planning to have the desired effect both in the systemic and organizational level [61]. Searching for short-term results presents negative results for firms and managers that do so [55]. The current international economic context demands, in addition to financial gains, results aligned with the principles of sustainability and innovation [62].

The found practices support the work of [62], which holds that job generation and demand creation are guidelines in sustainable and developed countries. In order to alter the current business logic (profit), the application of a new business model is required, involving all the relevant parts in the implementation of a new, sustainable paradigm.

Table 3. Economic practices

\begin{tabular}{|c|c|}
\hline Category & Practices \\
\hline Economic performance & $\begin{array}{ll}\text { 1. } & \text { Strategic planning } \\
\text { 2. Investment in information security, IT solutions and } \\
\text { human resource } \\
\text { 3. Financial indicators } \\
\text { 4. Use of incentive laws }\end{array}$ \\
\hline Indirect economic impacts & $\begin{array}{l}\text { 1. Activities in strategic new markets } \\
\text { 2. Possibility of generating jobs } \\
\text { 3. Accessibility actions } \\
\text { 4. Adaptation to new economical context } \\
\text { 5. Driving local economies }\end{array}$ \\
\hline Procurement practices & $\begin{array}{l}\text { 1. Procurement Professional Code of Ethical Conduct } \\
\text { 2. Comply with corporate social responsibility } \\
\text { 3. Focus on local suppliers }\end{array}$ \\
\hline
\end{tabular}

Firms that avoid taking risks allocate part of their investments into sustainable practices based on profitability and, when they fail to present the expected returns, those practices are terminated [55]. Highlighting that, despite the pressure from society for sustainable actions that meet the current market needs, it is the manager's responsibility to maintain the organization within a minimal level of profitability in which the activities are simultaneously sustainable and profitable; otherwise, the firm will be subject to failure [63]. The responsibility to create a sustainable environment within its supply chain and productive methods belongs to the organization, capable of providing the expected profit without harming the outside environment [41]. 


\subsection{Sustainable Practices—Social Category}

The social category has subcategories that encompass different aspects, from the treatment of collaborators to the community in which the firm is inserted. The influence of firms on their communities is tangible [64]. The social matter is a challenge for managers due to the search for a balance between the ethical standards demanded by the market and social responsibilities [65]. Our findings amplify the work of [55], showing the concern of organizations in creating value for their business through the appreciation and maintenance of their talents (benefit packages, career plans, salaries, quality of working life, and incentive to corporate education).

Companies must balance the income plans with environmental conservation and social justice [1]. Table 4 shows these practices and the results indicate meritocracy in hiring and promotions, but they do not objectively explain how this situation is measured and exposed to their collaborators, challenge companies further to provide awards based on employees' helping drive OS. Meritocracy needs to be defined and documented so as to increase the reliability, productivity, and smoothness of the process [66].

Table 4. Social practices.

\begin{tabular}{|c|c|}
\hline $\begin{array}{l}\text { Subcategory: Labor Practices and } \\
\text { Decent Work }\end{array}$ & Practices \\
\hline Employment & $\begin{array}{l}\text { 1. Benefits package (e.g., health insurance, postgraduate studies, etc.) } \\
\text { 2. Career development policy and salary } \\
\text { 3. Trainee program } \\
\text { 4. Attraction and retention of talent } \\
\text { 5. Internal recruitment }\end{array}$ \\
\hline Health and safety at work & $\begin{array}{l}\text { 1. Quality of working life } \\
\text { 2. Ergonomic conditions } \\
\text { 3. Educational campaigns (e.g., smoking, sedentary, etc.) }\end{array}$ \\
\hline Training and education & $\begin{array}{l}\text { 1. Corporate University } \\
\text { 2. Learning paths } \\
\text { 3. Financial in graduation and postgraduate } \\
\text { 4. Retirement plans for the employees } \\
\text { 5. Internal career development: e.g., leadership, goals orientation }\end{array}$ \\
\hline Diversity and equality of opportunity & 1. Meritocracy in hiring and promotions \\
\hline Equal remuneration for women and men & 1. Career plan and salary \\
\hline Supplier assessment for labor practices & $\begin{array}{l}\text { 1. Code of Ethical Conduct } \\
\text { 2. Compliance with labor, fiscal and the pertinent laws and regulations } \\
\text { 3. Compliance with preventing and combating corruption; } \\
\text { 4. Compliance with environmental preservation measures and social questions; }\end{array}$ \\
\hline Subcategory: Society & Practices \\
\hline Local communities & $\begin{array}{l}\text { 1. Sponsorship: educational, cultural and sporting projects } \\
\text { 2. Financial education for young people up to } 17 \text { years and retirees } \\
\text { 3. Volunteer work program } \\
\text { 4. Financial donations for charity institutions } \\
\text { 5. Initiatives funded by incentives laws }\end{array}$ \\
\hline Anti-corruption & $\begin{array}{l}\text { 1. Corporate anti-corruption policy and standard } \\
\text { 2. Ethical code } \\
\text { 3. Communication channel for complaints about corruption and bullying } \\
\text { 4. Online and face-to-face anti-corruption training }\end{array}$ \\
\hline Child labor/forced or compulsory labor & $\begin{array}{l}\text { 1. } \quad \text { Supplier audit } \\
\text { 2. } \quad \text { Contracts }\end{array}$ \\
\hline Response to disasters/emergencies & Contingency plan if applicable \\
\hline
\end{tabular}


Table 4. Cont.

\begin{tabular}{lll}
\hline Subcategory: Product Responsibility & \multicolumn{2}{l}{ Practices } \\
\hline & 1. & Digital security \\
Client health and safety & 2. & Privacy and responsibility in internet \\
& 3. & Post sale program \\
& 4. & Security internet for children \\
\hline \multirow{2}{*}{ Product and service labeling } & 1. & Customer Relationship Management \\
& 2. & Networks \\
& 3. & Digital channels \\
\hline
\end{tabular}

Regarding the suppliers, legal demands and features intrinsic to the firm are defined in contracts that determine their duties and responsibilities. Suppliers must be engaged in the organizational processes, assuming their responsibility in them [40]. Firms need to interact in environmental and humanitarian matters, seeking to contribute to the implementation of sustainability as a whole with more social activities [26].

The results prove that with the promotion of sports and cultural sponsorship campaigns using fiscal benefits and the creation of volunteer programs in which employees are invited to participate voluntarily in social actions performed by the firm. Thus, firms have been taking into account internal and external social matters, dealing with ethical and moral questions [64]. Moreover, there needs to be a distribution of the attributions among the main actors of society, seeing that the state no longer has the structure to manage all of those activities by itself [5].

Since organizations are part of a system, they must not merely solve a problem, but rather act in a preventive manner, in which those social investments become tools that contribute to the sustainable development of the entire system [26]. Although there are market segments that downplay the social responsibility of organizations, penalizing society and hatching new businesses [55], it is noticeable that business sustainability creates a knowledge set capable of integrating several organizational sectors, contributing to the establishment of objectives and goals toward the gradual and practical implementation of sustainable practices in firms [67]. The organization's business model and segment determine which actions are necessary for it to be able to implement its sustainable measures [67].

Although there are diverse activities, firms are still unable to follow a sustainable acting pattern due to the volatility of their segments, profits and adaptation to market conditions $[9,31]$. New opportunities arise when organizations know the inherent risks of their economic, social, and environmental objectives, reaping results in medium and long-term, in addition to a new set of sustainable, innovative responsibilities [68]. Firms that maintain excellence in their financial management without disregarding social matters are able to establish solid grounds for maintaining the premises of sustainability [64]. Our findings corroborate the work of [68], who stress that organizations must keep the focus on monitoring and reporting their sustainability goals.

\section{Conclusions}

This article analyzed the sustainability reports of firms listed by the CSI over the 2012-2016 period, which utilize the GRI methodology to present their sustainable practices to their stakeholders. The information contained in those reports are crucial for all the person and stages involved in this process. We found that the firms that participate in the CSI are all large and therefore, have more resources available to invest in sustainability. We also found that firms that have been publishing their sustainability reports for longer present more detailed information, which demonstrates organizational maturity.

Although organizations present these reports voluntarily, we notice their commitment to finding an ideal plateau, balancing results, deadlines, and investments, having to innovate in their activities and products. Our findings are practical and applicable in any firm, based on the realization of a strategic planning that defines deadlines, implements these practices, and analyzes their results. 
However, we stress that what works for one organization may not have the same results for another due to size, location, public vs private, goods vs services, time and effort pursuing sustainability, level of employee engagement in sustainability, etc.

The environmental practices involved the entire chain involved, observing the use of natural sources, specific environmental legislation and based on environmental contracts with suppliers and thirds. The economic practices are based on a strategic planning and development of new markets and the social practices are based on the human resources and the communities involved. We highlight that we did not find criteria for the implementation of meritocracy, and that a few extremely subjective questions still need to be documented.

Therefore, in order to apply the results found, managers must not search for the ideal solution for their organization, but rather draft a strategy that respects their particularities, culture, and resources, and only then define their sustainable objectives. This article may provide a new look at sustainability where its superficiality is replaced by practical and objective activities, which managers can direct or update according to their priorities of sustainable investments, knowing that the same activities are utilized by firms recognized by third parties as sustainable.

Analyzing their own processes, replacing the use of natural resources when possible and looking for updates to the available structure (e.g., new technologies) may be the first step to initiate an OS goal. This work recognizes the limitation of analyzing only firms that act in the service sector of the Brazilian market. Widening the scope of firms and seeking practices in other countries and economic blocks are suggestions for future works, in addition to analyzing other economic sectors, such as industry and agriculture. Moreover, it is an opportunity to observe the utilization of other methodologies beyond GRI, in order to compare results and analyze the structures employed.

Author Contributions: Alamo Alexandre da Silva Batista and Antonio Carlos de Francisco conceived and developed the idea and reviewed the reports. Alamo Alexandre da Silva Batista and Antonio Carlos de Francisco analyzed the results and wrote the manuscript. All authors have read and approved the final manuscript.

Conflicts of Interest: The authors declare no conflict of interest.

\section{References}

1. Rodríguez-Olalla, A.; Avilés-Palacios, C. Integrating sustainability in organisations: An activity-based sustainability model. Sustainability 2017, 9, 1072. [CrossRef]

2. Siew, R.Y.J. A review of corporate sustainability reporting tools (SRTs). J. Environ. Manag. 2015, 164, $180-195$. [CrossRef] [PubMed]

3. Amui, L.B.L.; Jabbour, C.J.C.; de Sousa Jabbour, A.B.L.; Kannan, D. Sustainability as a dynamic organizational capability: A systematic review and a future agenda toward a sustainable transition. J. Clean. Prod. 2017, 142, 308-322. [CrossRef]

4. Baviera-Puig, A.; Gómez-Navarro, T.; García-Melón, M.; García-Martínez, G. Assessing the communication quality of CSR reports. A case study on four Spanish food companies. Sustainability 2015, 7, 11010-11031. [CrossRef]

5. Antal, A.B.; Oppen, M.; Sobczak, A. (Re)discovering the social responsibility of business in Germany. J. Bus. Ethics 2009, 89, 285-301. [CrossRef]

6. Del Mar Alonso-Almeida, M.; Llach, J.; Marimon, F. A closer look at the "Global Reporting Initiative" sustainability reporting as a tool to implement environmental and social policies: A worldwide sector analysis. Corp. Soc. Responsib. Environ. Manag. 2014, 21, 318-335. [CrossRef]

7. Hahn, T.; Pinkse, J.; Preuss, L.; Figge, F. Tensions in Corporate Sustainability: Towards an Integrative Framework. J. Bus. Ethics 2015, 127, 297-316. [CrossRef]

8. Lozano, R. A holistic perspective on corporate sustainability drivers. Corp. Soc. Responsib. Environ. Manag. 2015, 22, 32-44. [CrossRef]

9. Morioka, S.N.; Carvalho, M.M. Measuring sustainability in practice: Exploring the inclusion of sustainability into corporate performance systems in Brazilian case studies. J. Clean. Prod. 2016, 136, 123-133. [CrossRef]

10. Pavláková Dočekalová, M.; Doubravský, K.; Dohnal, M.; Kocmanová, A. Evaluations of corporate sustainability indicators based on fuzzy similarity graphs. Ecol. Indic. 2017, 78, 108-114. [CrossRef] 
11. Deng, H. Multicriteria analysis for benchmarking sustainability development. Benchmarking Int. J. 2015, 22, 791-807. [CrossRef]

12. Sukitsch, M.; Engert, S.; Baumgartner, R.J. The implementation of corporate sustainability in the European automotive industry: An analysis of sustainability reports. Sustainability 2015, 7, 11504-11531. [CrossRef]

13. Longoni, A.; Cagliano, R. Sustainable Innovativeness and the Triple Bottom Line: The Role of Organizational Time Perspective. J. Bus. Ethics 2016. [CrossRef]

14. Falle, S.; Rauter, R.; Engert, S.; Baumgartner, R.J. Sustainability management with the Sustainability Balanced Scorecard in SMEs: Findings from an Austrian case study. Sustainability 2016, 8, 545. [CrossRef]

15. Klewitz, J.; Hansen, E.G. Sustainability-oriented innovation of SMEs: A systematic review. J. Clean. Prod. 2014, 65, 57-75. [CrossRef]

16. Brundtland, G.H. Our Common Future: Report of the World Commission on Environment and Development. Med. Confl. Surviv. 1987, 4, 300.

17. Keskin, D.; Diehl, J.C.; Molenaar, N. Innovation process of new ventures driven by sustainability. J. Clean. Prod. 2013, 45, 50-60. [CrossRef]

18. Elkington, J. Cannibals with Forks: The Triple Bottom Line of 21st Century Business; Capstone: Oxford, UK, 1997.

19. Clarke-Sather, A.R.; Hutchins, M.J.; Zhang, Q.; Gershenson, J.K.; Sutherland, J.W. Development of social, environmental, and economic indicators for a small/medium enterprise. Int. J. Account. Inf. Manag. 2011, 19, 247-266. [CrossRef]

20. Hannouf, M.; Assefa, G. Subcategory assessment method for social life cycle assessment: A case study of high-density polyethylene production in Alberta, Canada. Int. J. Life Cycle Assess. 2018, 23, 116-132. [CrossRef]

21. Garcia, S.; Cintra, Y.; de Cássia, S.R.; Torres, R.; Lima, F.G. Corporate sustainability management: A proposed multi-criteria model to support balanced decision-making. J. Clean. Prod. 2016, 136, 181-196. [CrossRef]

22. Luz, L.M.; De Francisco, A.C.; Piekarski, C.M. Proposed model for assessing the contribution of the indicators obtained from the analysis of life-cycle inventory to the generation of industry innovation. J. Clean. Prod. 2015, 96, 339-348. [CrossRef]

23. Antolín-López, R.; Delgado-Ceballos, J.; Montiel, I. Deconstructing corporate sustainability: A comparison of different stakeholder metrics. J. Clean. Prod. 2016, 136, 5-17. [CrossRef]

24. Thijssens, T.; Bollen, L.; Hassink, H. Managing sustainability reporting: Many ways to publish exemplary reports. J. Clean. Prod. 2016, 136, 86-101. [CrossRef]

25. Hahn, R.; Kühnen, M. Determinants of sustainability reporting: A review of results, trends, theory, and opportunities in an expanding field of research. J. Clean. Prod. 2013, 59, 5-21. [CrossRef]

26. Isaksson, R.B.; Garvare, R.; Johnson, M. The crippled bottom line-Measuring and managing sustainability. Int. J. Product. Perform. Manag. 2015, 43, 432-447. [CrossRef]

27. Lozano, R. Sustainability inter-linkages in reporting vindicated: A study of European companies. J. Clean. Prod. 2013, 51, 57-65. [CrossRef]

28. Morioka, S.N.; de Carvalho, M.M. A systematic literature review towards a conceptual framework for integrating sustainability performance into business. J. Clean. Prod. 2016, 136, 134-146. [CrossRef]

29. Cunha, F.A.F.S.; Samanez, C.P. Performance Analysis of Sustainable Investments in the Brazilian Stock Market: A Study about the Corporate Sustainability Index (ISE). J. Bus. Ethics 2012, 117, 19-36.

30. BM\&FBOVESPA Índice de Sustentabilidade Empresarial (ISE). Available online: http:/ / isebvmf.com.br/oque-e-o-ise?locale=pt-br (accessed on 8 May 2017).

31. Santis, P.; Albuquerque, A.; Lizarelli, F. Do sustainable companies have a better financial performance? A study on Brazilian public companies. J. Clean. Prod. 2016, 133, 735-745. [CrossRef]

32. Organization, I.L. ILOSTAT Country Profiles. Available online: https://www.ilo.org/ilostatcp/CPDesktop/ ?list=true\&lang=en\&country=BRA (accessed on 13 January 2018).

33. IBGE. Contas Nacionais Trimestrais: Indicadores de Volumes e Valores Correntes; Instituto Brasileiro de Geografia e Estatística: Rio de Janeiro, Brasil, 2017.

34. Bank, W. World Development Indicators. Available online: http://databank.worldbank.org/data/Views / Reports / ReportWidgetCustom.aspx?Report_Name=CountryProfile\&Id=b450fd57\&tbar=y\&dd=y\&inf= $n \& z m=n \&$ country=BRA (accessed on 25 July 2017). 
35. Lozano, R.; Ceulemans, K.; Scarff Seatter, C. Teaching organisational change management for sustainability: Designing and delivering a course at the University of Leeds to better prepare future sustainability change agents. J. Clean. Prod. 2015, 106, 205-215. [CrossRef]

36. Lloret, A. Modeling corporate sustainability strategy. J. Bus. Res. 2015, 69, 418-425. [CrossRef]

37. Engert, S.; Baumgartner, R.J. Corporate sustainability strategy-Bridging the gap between formulation and implementation. J. Clean. Prod. 2016, 113, 822-834. [CrossRef]

38. Toppinen, A.; Korhonen-Kurki, K. Global Reporting Initiative and social impact in managing corporate responsibility: A case study of three multinationals in the forest industry. Bus. Ethics 2013, 22, 202-217. [CrossRef]

39. Ceulemans, K.; Lozano, R.; del Mar Alonso-Almeida, M. Sustainability reporting in higher education: Interconnecting the reporting process and organisational change management for sustainability. Sustainability 2015, 7, 8881-8903. [CrossRef]

40. Lozano, R.; Nummert, B.; Ceulemans, K. Elucidating the relationship between Sustainability Reporting and Organisational Change Management for Sustainability. J. Clean. Prod. 2016, 125, 168-188. [CrossRef]

41. Foran, B.; Lenzen, M.; Dey, C.; Bilek, M. Integrating sustainable chain management with triple bottom line accounting. Ecol. Econ. 2005, 52, 143-157. [CrossRef]

42. Salvioni, D.M.; Franzoni, S.; Cassano, R. Sustainability in the Higher Education System: An Opportunity to Improve Quality and Image. Sustainability 2017, 9, 914. [CrossRef]

43. Orsato, R.J.; Garcia, A.; Mendes-Da-Silva, W.; Simonetti, R.; Monzoni, M. Sustainability indexes: Why join in? A study of the "corporate sustainability index (ISE)" in Brazil. J. Clean. Prod. 2015, 96, 161-170. [CrossRef]

44. Lourenço, I.C.; Branco, M.C. Determinants of corporate sustainability performance in emerging markets: The Brazilian case. J. Clean. Prod. 2013, 57, 134-141. [CrossRef]

45. Yu, M.; Zhao, R. Sustainability and firm valuation: An international investigation. Int. J. Account. Inf. Manag. 2015, 23, 289-307. [CrossRef]

46. Marcondes, A.W.; Bacarji, C.D. ISE: Sustentabilidade No Mercado de Capitais; Report. São Paulo, Brazil, 2010. Available online: http:/ / hdl.handle.net/10438/15424 (accessed on 17 January 2018).

47. Mdic, M. Da Industria Comercio Exterior e Serviços A Importância do Setor Terciário. Available online: http:/ / www.mdic.gov.br/index.php/comercio-servicos/a-secretaria-de-comercio-e-servicos-scs / 402-a-importancia-do-setor-terciario (accessed on 27 July 2017).

48. Ministério do Desenvolvimento, Indústria e Comércio Exterior (MDIC); Instituto Brasileiro de Geografia e Estatística (IBGE); Instituto de Pesquisa Econômica Aplicada (IPEA); Serviço Brasileiro de Apoio às Micro e Pequenas Empresa (SEBRAE). Atlas Nacional de Comércio e Serviços, 1st ed.; ABDI: Brasilia, Brazil, 2013.

49. Lage Junior, M.; Godinho Filho, M. Variations of the kanban system: Literature review and classification. Int. J. Prod. Econ. 2010, 125, 13-21. [CrossRef]

50. Fifka, M.S.; Drabble, M. Focus and Standardization of Sustainability Reporting-A Comparative Study of the United Kingdom and Finland. Bus. Strategy Environ. 2012, 21, 455-474. [CrossRef]

51. Bellantuono, N.; Pontrandolfo, P.; Scozzi, B. Capturing the stakeholders' view in sustainability reporting: A novel approach. Sustainability 2016, 8, 379. [CrossRef]

52. Moneva, J.M.; Ortas, E. Corporate environmental and financial performance: A multivariate approach. Ind. Manag. Data Syst. 2010, 110, 193-210. [CrossRef]

53. Ortas, E.; Gallego-Alvarez, I.; Álvarez Etxeberria, I. Financial Factors Influencing the Quality of Corporate Social Responsibility and Environmental Management Disclosure: A Quantile Regression Approach. Corp. Soc. Responsib. Environ. Manag. 2015, 22, 362-380. [CrossRef]

54. De Abreu, M.C.S. How to define an environmental policy to improve corporate sustainability in developing countries. Bus. Strategy Environ. 2009, 18, 542-556. [CrossRef]

55. Perrini, F.; Russo, A.; Tencati, A.; Vurro, C. Deconstructing the Relationship between Corporate Social and Financial Performance. J. Bus. Ethics 2011, 102, 59-76. [CrossRef]

56. De Fátima de Oliveira Miranda Santos, S.; Piekarski, C.M.; Ugaya, C.M.L.; Donato, D.B.; Braghini, A.; de Francisco, A.C.; Carvalho, A.M.M.L. Life cycle analysis of charcoal production in masonry kilns with and without carbonization process generated gas combustion. Sustainability 2017, 9, 1558. [CrossRef]

57. Delmas, M.; Blass, V.D. Measuring Corporate Environmental Performance: The Trade-Offs of Sustainability Ratings. Bus. Strategy Environ. 2010, 19, 245-260. [CrossRef] 
58. Yang, Z.; Liu, W.; Sun, J.; Zhang, Y. Corporate environmental responsibility and environmental non-governmental organizations in China. Sustainability 2017, 9, 1756. [CrossRef]

59. Hardjono, T.; De Klein, P. Introduction on the European Corporate Sustainability Framework (ECSF). J. Bus. Ethics 2004, 55, 99-113. [CrossRef]

60. Osagie, E.R.; Wesselink, R.; Blok, V.; Lans, T.; Mulder, M. Individual Competencies for Corporate Social Responsibility: A Literature and Practice Perspective. J. Bus. Ethics 2014, 135, 233-252. [CrossRef]

61. Vildåsen, S.S.; Keitsch, M.; Fet, A.M. Clarifying the Epistemology of Corporate Sustainability. Ecol. Econ. 2017, 138, 40-46. [CrossRef]

62. Boons, F.; Montalvo, C.; Quist, J.; Wagner, M. Sustainable innovation, business models and economic performance: An overview. J. Clean. Prod. 2013, 45, 1-8. [CrossRef]

63. Weyzig, F. Political and economic arguments for corporate social responsibility: Analysis and a proposition regarding the CSR agenda. J. Bus. Ethics 2009, 86, 417-428. [CrossRef]

64. Cornelius, N.; Todres, M.; Janjuha-Jivraj, S.; Woods, A.; Wallace, J. Corporate social responsibility and the social enterprise. J. Bus. Ethics 2008, 81, 355-370. [CrossRef]

65. Morimoto, R.; Ash, J.; Hope, C. Corporate social responsibility audit: From theory to practice. J. Bus. Ethics 2005, 62, 315-325. [CrossRef]

66. Rhaiem, M. Measurement and determinants of academic research efficiency: A systematic review of the evidence. Scientometrics 2017, 110, 581-615. [CrossRef]

67. Pojasek, R.B. A framework for business sustainability. Environ. Qual. Manag. 2007, 17, 81-88. [CrossRef]

68. Chakrabarty, S.; Wang, L. The Long-Term Sustenance of Sustainability Practices in MNCs: A Dynamic Capabilities Perspective of the Role of R\&D and Internationalization. J. Bus. Ethics 2012, 110, 205-217.

(C) 2018 by the authors. Licensee MDPI, Basel, Switzerland. This article is an open access article distributed under the terms and conditions of the Creative Commons Attribution (CC BY) license (http:/ / creativecommons.org/licenses/by/4.0/). 